\title{
SOCIO-POLITICAL MANIPULATION - INCIDENTAL PATHOLOGY OR IMMANENT COMPONENT OF INTERNATIONAL REALM?
}

Manipulation as a method of influence is one of the most subtle and yet most ruthless forms of shaping social behaviour. Along with other means of pressure: coercion, persuasion and violence, manipulation is strongly related to the nature of human interactions - specific for highly complex mental and cultural conditions of their occurrence. As a natural consequence of human pursuit of higher needs, it can be observed right on the field of common personal interactions. According to the hierarchy established by Abraham Maslow, manipulative tendencies are inseparably connected with the need of belonging and recognition, usually as a mechanism of gaining (or undermining) social approval and shaping the reality with one's own vision of the world. ${ }^{1}$ As a result, manipulation works in many diversified forms and penetrates numerous areas of social activity. Among them, however, there are fields where that particular form of shaping awareness gained a special dimension under the terms of institutionalized, organized and multi-ranged influence strategy.

The aforementioned type of social pressure has been widely applied especially in the sphere of professional development of the social decision-making. The fundations for expansion of such techniques were laid down through the arts of dialectic and eristic, which principles were further incorporated into countless areas of professional activity. Application of given scheme found its foothold in borderland between fields of economics, politics and administration, where manipulative techniques has been improved in the context of specific concepts of marketing, promotion and management. Remaining in a clear correlation with the aforementioned phenomenon, effective methods of creating public moods have also been developed in the field of mass media and distribution of information.

Due to such a wide range of selections under the socio-political concept of manipulation itself, this particular issue has become an object of deep interest of nearly every one of the numerous fields of social science, often highly diversified by means of methods, concepts and points of reference assumed. As a result, many streams of interpretation of that phenomenon were created, emphasising various aspects of its occurrence - originally different for sociology, psychology or political sciences. Simultaneously, some theoretical approaches that were developing in a parallel manner, were also naturally penetrating one another. The reason was the vagueness anchored deeply in the

${ }^{1}$ G. Hartley, M. Karinch, Podręcznik manipulacji, Warszawa 2011, pp. 16-17. 
essence of manipulation and its tendency to diffuse throughout various aspects of interests within its area of occurrence (for instance, exerting political influence in order to achieve particular economical benefit).

The scope of aforementioned dependencies also included the sphere of international relations where the concept of manipulation easily falls within categories of diplomatic, business, or ideology-related activities. The fact that it emerges from elementary human inclinations did not mean, however, that the concept of manipulation in international relations simply reflects personal interactions (though it frequently remains closely linked to them, which can be noticed, for instance, within essence of individual diplomatic relations). The character of that phenomenon has always been difficult to classify for huge diversity of patterns as well as for the nature of manipulation itself as a process of enigmatic characteristics whose greatest efficiency depends on concealing its objectively identifiable entity.

Thus, defining the real meaning of socio-political manipulation in international relations requires not only prior specification of the theoretical frame of the phenomenon but also precise indication of applicable techniques. In that context, the analysis should begin with identifying the conditions that differentiate manipulation from the other methods of exerting influence, especially from persuasion that is related to it. A separate distinction must be made for indicators of manipulation's specificity within international sphere and its difference from other dimensions of that phenomenon which do not have global character. Do they also include techniques of social influence applied locally, in a limited ecumene, which though express a universal model of behaviour? Which of the identified groups should for instance heresthetics - the strategy of political influence on the voters' will that is practiced globally but as a set of independent editions - be classified into?

In the context of heresthetics, the elementary problem of the concept of manipulation becomes even more noticeable. Its presence has been signalised by the author of the aforementioned idea, William H. Riker, who claimed that heresthetics cannot be perceived as a scientific category or a set of rules meant to be a guideline for effective strategies of influence, describing it explicitly as a kind of art. By that means, is there any clue for scientific cognition of manipulation claimed by its own investigators not to be a technique of influence but rather a kind of a subtle "play on emotions".

Providing answers to the given questions remains a vital condition for indicating the theoretical frames for further analysis of socio-political manipulation in the scope of international relations. Effective examination of that phenomenon also requires a recognition of its empirically confirmed incarnations and the historical process of its transformation. Under these terms, the final aim of discourse is to predict ways of development for the discussed phenomenon in the context of global situation in the nearest future.

2 W. H. Riker, The Art of Political Manipulation, New Haven 1986, p. IX. 


\section{THE THEORY OF MANIPULATION IN INTERNATIONAL RELATIONS - THE SCOPE OF PHENOMENON}

The interest of international relations focuses merely on a limited fragment of the issue of manipulation in its socio-political dimension. Nevertheless, the range of whole phenomena considered on the basis of the theory of international relations is so wide and diversified that it requires a definition of the entire phenomenon in its broad meaning, universal for all the social sciences. Such necessity is biult upon the synthetic and multi-dimensional origin of manipulation techniques, deeply rooted in many related areas of examination such as psychology, sociology or political sciences at the same time.

As a social phenomenon, manipulation appears mostly on the linguistic level reflecting its strong ties with matter of the rhetoric. Therefore, numerous definitions of that category of influence refer to the pejoratively regarded communication tricks being used under the terms of dialectic and eristic. The main determinant of such a concept of manipulation is shaping of attitudes and activities of the object which is not aware of the intentions hidden behind influence in a way demanded by the subject. The relation developed is non-equivalent and the subjectivity of the recipient is always, to a minor or major extent, limited at stake to the sender's aim to achieve a proper feedback. ${ }^{3}$

The aforementioned dependency can easily be transferred onto the field of the general theory of social influence. The notion of manipulation in social sciences is strongly connected with the categories of power, superiority and subordination of will, no matter whether or not the given phenomena are political in nature. The will as an ability of conscious, intentional and unconstrained taking or abstaining from taking actions is the object of executing power. Authority can, therefore, be referred to as social relation whose essence lies in imposing the will of one subject onto the other by constraining or withholding the will of the latter. ${ }^{4}$ Described understanding of power was specified by Max Weber, who defined that category as "an unlimited possibility of fulfilling one's will within the given social relations regardless of any objections and of the background that the possibility originates from".

The issue of exerting influence including, in a natural manner, any aspects of manipulation, is based on assumptions close to those indicated in the mentioned definition of power. As Mirosław Karwat indicates, each form of influence is a kind of pressure, breaking the resistance. In his opinion, it mainly refers to the area of political and ideological domination where influence is most usually identified as imposing one's own will. ${ }^{6}$ Just like power, influence is based on the relation between superiority and subordination. The possibility of enforcing one's own vision of the reality results from the ability to capture the attention of others to one's postulates and to engage them in

3 J. Bralczyk, Manipulacja językowa, in: Dziennikarstwo i świat mediów, (eds.) Z. Bauer, E. Chudziński, Kraków 2000, pp. 244-245.

4 A. Czajkowski, Wtadza polityczna. Analiza pojęcia, in: Studia z teorii polityki, (eds.) A. W. Jabłoński, L. Sobkowiak, Wrocław 1999, p. 36.

${ }_{5}$ M. Weber, Wirtschaft und Gesellschaft. Cited after: A. Czajkowski, Władza polityczna. Analiza pojęcia, op. cit., pp. 36-37.

6 M. Karwat, Sztuka manipulacji politycznej, Toruń 2001, p. 23. 
a group activity managed by the subject with the specific objectives and values. According to M. Karwat, an adequately high superiority rate of the agent of influence over dependent subject resulting in long-term obedience, can be regarded as a relation of power. ${ }^{7}$ The relation between these two categories is confirmed by the fact that both phenomena generate each other in a mutual manner - thus, exerting social influence is meant to enhance power and holding power is supposed to assure the continuity of developing influence. ${ }^{8}$ In effect, influence is one of the basic attributes of power and it is most frequently observed in its context.

Although both categories are identical in terms of ability to shape the will of the subordinate they differ from each other in range and forms of dependency they include. First of all, influence appears as a broader concept, considerably exceeding the limits of the concept of power - it includes any relationships of domination, also these existing within the sphere of informal groups and private organisations. Influence slips out of the scope of power when pressure has no sanction for the potential disobedience or when the subjects unconsciously affect each other. ${ }^{9}$

Still, the borderline between the authoritarian and non-authoritarian pressure remains vague, and the above mentioned types of influence penetrate and complement each other in the social reality. It is clearly reflected in the process of socialisation conducted by numerous public and private institutions and associations: families, education units, the Church, mass media and peer or profession groups. A matter that especially remains in a close correlation with authoritative creation of social behaviours is sociotechnics - a process of re-production of the social order operating on the basis of transforming the society into the demanded direction..$^{10}$ The broadest influence range is tied directly to the political dimension of social engineering which represents the crucial context of the state-power. It involves the entire society and the whole range of existing inter-human relations within a given political system.

From the perspective of political interaction, the field of sociotechnics does not only illustrate the authoritarian demand for social obedience but also demonstrates certain correspondence with the area of persuasion and manipulation techniques. Although social engineering is not supposed to be identified with the pejoratively marked notion of manipulation, it often reaches for tools strongly tied to the field of insidious social influence. The fact that the mentioned categories overlap is reflected especially in the concept of propaganda that is characteristic of both of them. Recently interpreted as an "invasively" marked method of dissemination of messages glorifying and promoting certain ideas at the cost of sacrificing others, propaganda applies numerous tricks in order to gain social approval for the status quo. Therefore, the mechanism indicated is often viewed, right next to the category of news (transfer of information), as one of the two basic channels of political communication where it plays the role of the influence

${ }^{7}$ Ibidem.

8 A. Czajkowski, Władza polityczna. Analiza pojęcia, op. cit., p. 40.

9 Ibidem, pp. 30-31.

${ }^{10}$ Introduction, Problemy wspótczesnej demokracji w ujęciu socjotechnicznym, (ed.) P. Pawełczyk, Poznań 2005, p. 5; Item: P. Pawełczyk, D. Piontek, Socjotechnika w komunikowaniu politycznym, Poznań 1999, pp. 11, 48, 61. 
medium. However, the definition of propaganda is often confined straight to specific techniques of social engineering where it is identified with organized persuasion or manipulation. ${ }^{11}$ Associating propaganda with manipulation seems to be suggested also by the precursor of research over that phenomenon, Edward L. Bernays, himself. In his work, he compared "a new propaganda" to the mechanism of control of the public mind and manipulative strategy used by "special pleader who seeks to create public acceptance for a particular idea or commodity". ${ }^{2}$

The persuasive aspect of propaganda was, in turn, noticed by Janina Fras who indicated language as an excellent channel of influence which is successfully used by the authors of propaganda messages. ${ }^{13}$ The aforementioned dimension was also observed by researchers such as Elliot Aronson and Anthony Pratkanis. They used the idea of propaganda with reference to the "techniques of mass persuasion" applied in post-industrial societies. ${ }^{14}$ Nevertheless, it should be emphasised that this reference was made by the authors in such a manner that it slips out of the scope of the classic persuasion. The idea of propaganda represented by them in many cases combined the persuasive instruments with purely manipulative techniques, excluding, at the same time, certain aspects of persuasion (typical of debates, discussions and other forms of arguments in favour of "informing and enlightening" that do not carry any implied meanings). ${ }^{15}$ Associating given frame of propaganda with manipulation resulted from considering falsity and deceit as an integral part of the area of propaganda. The authors also referred to that issue while discussing the historical process of the evolution of propaganda where they indicated that the idea of suggestion and influence whose realization was guaranteed by manipulating symbols and by taking advantage of the recipient's mental proneness.

The effect of such a definition of the persuasive concept of propaganda was the statement that applying that instrument includes skilful use of images, keywords and signs referring to the prejudice and emotions of the subject. This, in turn, is meant to deliver a specific vision of reality to the recipient and inspire him to approve it in such a manner that the influenced subject considers it to be his own independent decision. ${ }^{16}$ As it is shown later in the present discourse, that fact demonstrates a considerable similarity between the concepts of propaganda put forward by Aronson-Pratkanis and influence exerted in a manipulative manner.

Mutual affection of manipulation and persuasion on the level of numerous renditions of propaganda confirmed the fact that there are many common points between these two categories of influence. The strongest relationship between manipulation and persuasion was presented on the level of language referring to rhetoric and eristic

11 P. Pawełczyk, D. Piontek, Socjotechnika w komunikowaniu politycznym, op. cit., pp. 38-39.

12 E. L. Bernays, Propaganda, New York 1928, p. 18.

13 J. Fras, Jezzyk propagandy politycznej, in: Teoria i praktyka propagandy, (eds.) B. Dobek-Ostrowska, J. Fras, B. Ociepka, Wrocław 1999, p. 84.

${ }^{14}$ E. Aronson. A. R. Pratkanis, Wiek propagandy. Używanie i nadużywanie perswazji na co dzień, Warszawa 2004, p. 17.

15 Ibidem, pp. 18-19.

16 Ibidem, p. 17. 
(methodology of effective convincing and disputing) where both categories frequently interwove in the context of unfair verbal confrontation. However, an extremely striking example of the correlation between manipulation and persuasion was only established by means of the category of coercive persuasion. This definition, formulated by Edgar Schein, was used for the first time with reference to the entire range of tricks applied by the Chinese authorities during the war in Korea towards the captive American prisoners who were prompted to acquire the communist ideology. ${ }^{17}$

Apart from the similarity resulting from the strong verbalisation and expressiveness of the described methods of exerting pressure, the most distinctive common feature of manipulation and persuasion is the capability of minor or major incapacitation of the "uncritical and unaware" influence recipient - in both cases he can behave in alignment with the sender's expectations bearing no awareness of the consequences. ${ }^{18}$ Furthermore, manipulation often functions while maintaining the pose of its persuasiveness, taking such a form in order to hide the real message of pressure. ${ }^{19}$ That fact generates considerable difficulties in differentiating between these two forms of influence, also on the grounds of the sciences researching the cases discussed above.

Nevertheless, manipulation and persuasion should be treated as separate categories of creating social awareness. The main difference between persuasion and manipulation is, first of all, the issue of respecting the subjectivity of the influence recipient - recognising their interests, beliefs and situation, which simultaneously determines the hierarchy of objectives of the pleader and the consequences of pressure for the recipient. ${ }^{20}$ Under that condition, Janina Fras claims that the essence of persuasive actions is to give the possibility of choice to the affected, thus presuming the existence of free will on the level of accepting the message. ${ }^{21}$ Manipulation makes it impossible for the recipient to notice other options, shaping the vision of reality in order to set the illusion of the persuasive message offering the best possible way out or the only existing solution.

As the related literature points out, there is also a difference between persuasion and manipulation when it comes to the openness (transparency) of intensions and the methods applied to achieve them, emphasising the inner coherence of the persuasive message and the veiled inconsistence between the content and the form in the manipulative interaction. Persuasion, as a process of prompting to choose a given option on the grounds of authentic arguments and objectively existing conditions, is based on pre-

${ }^{17}$ Generally speaking, persuasion understood in that way (colloquially referred to as brain-washing and in the scientific literature as psycho-manipulation) is based on the multi-dimensional and complex limitation of the abilities of the manipulated to make independent decisions - both by using constraint as well as by creating suitable conditions to acquire the message - the internal conviction of the recipient about the autonomous and ultimate nature of his decisions. J. Dressler, Professor Delgado's "Brainwashing" Defense: Courting a Determinist Legal System, "Minnesota Law Review” 1978, No 63, pp. 335-337; Item: E. Schein, Coercive Persuasion: A socio-psychological analysis of the "brainwashing" of American civilian prisoners by the Chinese Communists, New York 1971.

18 J. Fras, Język propagandy politycznej, op. cit., p. 84.

19 M. Karwat, Sztuka manipulacji politycznej, op. cit., p. 29.

20 Ibidem, pp. 26-27.

21 J. Fras, Język propagandy politycznej, op. cit., p. 84. 
senting the real target and standpoint on the issue disputed by the influencing subject. ${ }^{22}$ Manipulation, in turn, excludes in advance the possibility of making the object of influence aware of the real values, messages and intentions determining the interaction of the affected subject. ${ }^{23}$ It includes offering selective access to the information, which is extremely meaningful in terms of making decisions and taking stands by the recipient. Depending on the circumstances, it takes the form of creating a shortage or an excess (or so-called: overload) of information in order to make it impossible to carry out a rational calculation of the options available. ${ }^{24}$ Therefore, the very essence of manipulation is about convincing the influenced to accept the conditions which would be automatically questioned and rejected by aware and fully informed subject. ${ }^{25}$

The aforementioned understanding is usually a consequence of negatively marked axiological and teleological attitudes of the manipulating subject as well as the collision of interests or standpoints between the steering and the steered. That discrepancy is also observed when the objectives, values and benefits of the sender are incompatible with the expectations of the recipient or even harmful to him. ${ }^{26}$ The fact that this dissonance exists results in the fact that the appearance of manipulation is often associated with the presence of a conflict between the parties to the dependency relationship. Furthermore, a manipulative interaction is often based on creating the realities of confrontation and hostility, thus efficiently disintegrating the environment of the steered community or even destroying its inner structure. ${ }^{27}$ Reaching that state of affairs is possible by means of feeding extreme attitudes and provoking clashes of outlooks, which, in turn, leads to obstruction of remedial initiatives.

The aforementioned dependency that is very typical of manipulation, demonstrates the tendency of operating on non-rational determinants of human behaviours. Similarly to the control of information, the fact of referring to basic instincts and emotions is meant to distort the vision of reality perceived by the subject under pressure and constituting the basis of his decisions within the range referring to the interests of the manipulator. As Nikolaos Zahariadis claims in his studies, the indicated attribute of manipulation can also be confirmed on the level of international relations. The mentioned researcher emphasises that affecting emotions and "individual conditions" related to them constitute a fundament on which the institutionalised influence on the decision making in political process is based. ${ }^{28}$ Hence, the emotional direction of the

22 P. Pawełczyk, D. Piontek, Socjotechnika w komunikowaniu politycznym, op. cit., p. 64.

23 J. Fras, Język propagandy politycznej, op. cit., p. 97.

24 P. Chilton, Manipulation, Memes and Metaphors. The Case of Mein Kampf, in: Manipulation and Ideologies in the Twentieth Century, (eds.) L. de Saussure, P. Schulz, Philadelphia 2005, pp. 15-16; Item: P. Pawełczyk, D. Piontek, Socjotechnika w komunikowaniu politycznym, op. cit., p. 17.

${ }_{25}$ M. Cottam, B. Dietz-Uhler, E. Mastors, T. Preston, Introduction to Political Psychology, London 2004, p. 84.

${ }^{26}$ J. Fras, Język propagandy politycznej, op. cit., p. 97.

27 E. Stern, B. Sundelius, Understanding Small Group Decisions In Foreign Policy: Process Diagnosis and Reasearch Procedure, in: Beyond Groupthink: Political Group Dynamics and Foreign Policy Making, (eds.) P. 't Hart, E. Stern, B. Sundelius, Michigan 1997, p. 130.

${ }_{28}$ N. Zahariadis, Essence of Political Manipulation: Emotion, Institutions, \& Greek Foreign Policy, New York 2008, pp. 1-6, 36, 193-198. 
exerted pressure can be successfully regarded as an aspect of the socio-political transfer of the manipulation theory onto the field of international relations.

The references to the above mentioned model of manipulation, despite their clear outline at the beginning of $21^{\text {st }}$ century in N. Zahariadis, appeared within the streams of the theory of international relations long before the formal establishment of that field of science. They reached the early stages of forming the framework of international political thought, finding their reflection especially in the positions of such precursors of the realism theory as: Thucydides, Machiavelli and Hobbes. One of the conclusions of their studies was the claim that the human nature is egoistic and selfish, which determines the way the state politics is conducted, especially with respect to international relations. Targeted to reach the maximum of its effectiveness, policy subordinates moral regulations or operates in alignment with the rules of ethics merely when it serves (alternatively, when it does not interfere with) achieving the objectives. ${ }^{29}$ The fact that ethical borders are excluded in turn leaves room for the tendency of using manipulation as a mean of political affection. This indicates the existence of common denominator between the realistic model of international relations and the theory of socio-political manipulation that, in the opinion of Mirosław Karwat, is also based on cold calculation - selfish and ruthless intentionality of influence (whether or not it results in somebody else's harm). ${ }^{30}$

The tendency to seek convergence between the realistic vision of international politics and authoritarian manipulation occurred mainly in reference to the works of Nicollo Machiavelli. The theses he presented claimed that it is effectiveness - not ethics - that constitutes the basic assessment criterion of the political influence. ${ }^{31}$ In his opinion, it is the scale of social responsibility of the ruler that matters and he, in order to be able to bear it, is forced to reject moral values in the absolute sense and replace them with the system of relative values being in force only under given circumstances (determined by the rules of social opportunism). ${ }^{32}$

The fundament on which Machiavelli based his standpoint was the virtual and ambiguous nature of all things. Using it as the basis, he claimed that actions, rules and norms can, depending on the context, take the meaning inconsistent with their original axiomatic marking. In other words, qualities regarded as virtues can in certain circumstances have negative consequences and those referred to as vices may generate a positive change. Machiavelli, considering human qualities from the point of view of their political application and usefulness, suggested that benefits should be drawn both from honest actions as well as from actions that are morally reprehensible. He was, however, aware of the fact that the effectiveness of immoral behaviours depends on the publicly created illusion of their validity and of the ethicality of the premises. Hence, Machiavelli postulated the necessity of adapting to the natural state of ambiguity and

29 J. Czaputowicz, Teorie stosunków międzynarodowych. Krytyka i systematyzacja, Warszawa 2007, pp. 59-62.

30. Karwat, Sztuka manipulacji politycznej, op. cit., p. 14.

31 J. Czaputowicz, Teorie stosunków międzynarodowych. Krytyka i systematyzacja, op. cit., p. 64.

32 D. Maestripieri, Macachiavellian Intelligence. How Rhesus Macaques and Human Have Conquered The World, Chicago 2007, p. 4; Item: A. Riklin, Niccollo Machiavellego nauka o rzqdzeniu, Poznań 2000, pp. 30-32, 54-56. 
complexity of the world by participating in the charade and skilful manipulation of various images of the decision-maker and of the situations that occur. ${ }^{33}$

The combination of the conditions mentioned above determined the path combining the theory of political relations with manipulation techniques based on falsity, hypocrisy and relativity of meanings. The theses articulated by Machiavelli were also sustained by numerous subsequent representatives of realism in international relations. This was particularly true of the works of Edward Carr who drove the emergence of the realistic stream in the indicated field of science in the first half of the $20^{\text {th }}$ century. E. Carr also referred to Machiavelli's theses indicating that objective principles that rule politics take their origin from the human nature whereas morality should be fully subordinated to politics according to the rule that it is its effectiveness that determines its quality. Commitments should be kept by the state only till they cease to be beneficial. ${ }^{34}$

The content of the aforementioned theses was fixed in the theory of international relations also by subsequent well-known representatives of the realistic stream, such as Hans Morgenthau. A different approach to the issue of influence in international relations was, in turn, put forward by the representatives of numerous theoretical trends within constructivism and post-modernism. Those trends gained a good perspective for conducting investigations on that phenomenon thanks to putting a clear emphasis on the sociological aspects of the conditions of the international situation. To put it simply, it focused on recognizing the key role of an idea, a concept and of human interpretation in the process of developing that sphere. ${ }^{35}$ The observation that social facts are not independent from human intentional acting yet they exist thanks to the social agreement - they are facts because they are recognized as such by the society - was also significant in that context. ${ }^{36}$ Thus, a conclusion can be drawn that the international reality can be modified thanks to the appropriate influence on the human awareness and will, including influence through the methods of manipulation.

The range of reference to the issues of socio-political manipulation in the indicated theoretical trends took various forms depending on the level of relativism that they represent. The post-structural approach (associated with post-modernism) demonstrated a moderate level of relativism, postulating most of all the existence of objectively recognized structural entities that are independent of the human awareness though they interact along with constructs resulting from the emanation of social visions. The numerous varieties of social constructivism were more radical in emphasizing the relative character of meanings. The common standpoint they shared was that the international reality is not an independent being but the effect of interaction of state, national, and individual identities and socio-political interests. ${ }^{37}$ Those identities, in turn, emerge as a result of the distribution of values and ideas typical of a given socio-political system. ${ }^{38}$

33 A. Riklin, Niccollo Machiavellego nauka o rzqdzeniu, op. cit., pp. 96-107.

34 J. Czaputowicz, Teorie stosunków międzynarodowych. Krytyka i systematyzacja, op. cit., pp. 74-75.

35 R. Zenderowski, Stosunki międzynarodowe. Vademecum, Wrocław 2006, p. 65.

36 J. Czaputowicz, Teorie stosunków międzynarodowych. Krytyka i systematyzacja, op. cit., p. 306.

37 Ibidem, p. 302.

38 Different approaches emphasizing the role of axiological systems in creating the international reality were present in constructivism. The moderate variety of that trend marked with references to 
The vision of identity creation provided above, articulated by one of the authors of constructivism, Alexander Wendt, became a key theme of Zahariadis's explorations concerning the manipulative nature of international relations. The scientist referred to Wendt's thesis indicating that the material aspects of power are not as significant for the essence of the described relations as the character of knowledge distribution within the socio-political system. ${ }^{39}$ On that basis, Zahariadis put forward his own definition of manipulation in international relations with reference to the field of foreign affairs. He defined it as a "systematic distortion, misrepresentation, or selective presentation of information by skilled entrepreneurs who exploit opportunities in a policy world of unclear goals, opaque technology, and fluid participation". ${ }^{40}$

Contrary to what it may seem, the rhetoric and blurred character of the definition provided above adequately portrays the essence of manipulation - not only in the international sphere but also in the entire field of socio-political relations. The specific generality of Zahariadis's concept is, as if, constrained considering the multiplicity and diversity of the forms of interaction observed in the investigated area as well as the wide range of transformations they continuously undergo. With reference to the above, it should be noticed that a more precise definition of manipulation could result in overlooking many significant aspects of the discussed phenomenon. Recognising its basic expressions requires further considering the historical context of its occurrence.

\section{THE HISTORICAL BACKGROUND OF MANIPULATING ATTITUDES}

Many elements combining aforementioned conceptions of manipulation suggest the existence of a homogenous basis for appearance of such form of influence. Basing on the fact of their existence it can be ascertained that manipulation is basically a skilful usage of human weaknesses for the purpose of fulfilling own goals and realization of particular interests. That kind of interaction pattern was in use from the beginning of mankind and human civilization, with only realities, means and techniques of usage being changed.

positivism and structuralism was represented by Alexander Wendt. Apart from that, there also existed attitudes strictly anti- and post-positivistic that put much more stress on "idealism" and on the inter-subjective character of the cognition of the international reality; See more: A. Wendt, Social Theory of International Politics, Cambridge 1999, pp. 246-369.

39 Relations between the issues of knowledge and power were also noticed by Michel Foucault who indicated the ability of mutual creation of the discussed categories; Ibidem, p. 20; Item: N. Zahariadis, Essence of Political Manipulation: Emotion, Institutions, \& Greek Foreign Policy, op. cit., p. 196; S. Leitch, J. Motion, Discourse Theory, in: Encyclopedia of Public Relations, (ed.) R. L. Heath, Thousand Oaks 2005, Vol. 1, p. 258.

40 The context for developing the indicated definition of manipulation was the objection raised by Greece to the alleged acquisition by Macedonia of an integral part of their national identity (the name of Macedonia originally referred to the geographic territories remaining under the influence of the Greek culture). On the basis of that example, Zahariadis underlined the manipulative character of the dramatic changes in Greek foreign policy towards Macedonia - oscillating between confrontational and cooperative trends. N. Zahariadis, Essence of Political Manipulation: Emotion, Institutions, \& Greek Foreign Policy, op. cit., p. 22. 
Symbolic pattern of manipulation in the social relations has been reflected in the Bible, mainly in the story of temptation of first humans by Satan shown in the Book of Genesis. Deeming manipulation as one of the methods of affect used by "Forces of Evil" did not protect religion and systems of beliefs from using it as instrument of effective way to influence the society, when they showed their creative potential and ability to petrify political authority. Ancient priests, augurs and shamans fervently used an acquired knowledge to grant scientific laws supernatural character and symbolism, thus making the alleged authority of gods and divinities an instrument legitimizing their superiority and social control. The idea of God's anointment was also used by the rulers themselves. It was not only used vertically, in the relations with the common people, but also horizontally - on the level of cross-civilization relations, justifying one's own aspiration to dominate, conquer, and assimilate the less developed community with God's will.

Machiavelli was an advocate of viewing the qualities of religion in terms of its political benefit. He pointed out the possibilities offered by the systems of faith for the purposes of creating myths, formulating laws and prohibitions as well as imposing the appropriate direction onto social expectations. Machiavelli considered manipulation of dogmas, prophecies and auguries as a most effective, hence the most proper, method of gaining demanded feedback. It resolved down to no more no less but stimulation of social faith in transcendent reality and validation of a providence with image compliable with goals and intentions of authorities. In assessment constructed in that manner, Machiavelli classified religion as one of the most effective political instruments remaining under control of the state apparatus. ${ }^{41}$

The development of human socio-systemic organization was conducive to tightening the mutual interactions, thus making it possible to develop more and more effective methods of influence. The fact of applying manipulative techniques became more and more common along with the growth of the number of public life participants. An individual becoming part of the crowd presented stronger vulnerability to influence and skilful manipulation. The potential of that particular human inclination was observed, already in the ancient times, by the first teachers and rhetoric practitioners in which the sophists were dominant. Improving their skills in demagogy, they came to the conclusion that the community functioning in a congregation or at the court of justice is much more likely to yield to skilful instigations and suggestions. Aristotle explained the inclination by means of a simple dependency: "the bigger the crowd, the further the observation point", which illustrated the lowered ability to react to rhetoric tricks. ${ }^{42}$ Thus, the sophistic rhetoric focused on the methodology of attracting the audience by pushing the concern for axiological and theological level of argumentation to the background. That attitude was severely criticised by numerous philosophers, especially by Plato who identified it with the false and twisting demonstration of one's own seemingly valid arguments in front of the unaware audience.

The sophistic character of argumentation was enhanced, first of all, in the ancient judiciary tradition. Drawing attention to the immoral character of such techniques, the

41 A. Riklin, Niccollo Machiavelli's Science on Governing, op. cit., p. 74.

42 M. Korolko, Sztuka retoryki. Przewodnik encyklopedyczny, Warszawa 1990, pp. 40-41. 
Greek fraction of philosophical thought discussed the issue of the speaker's ethos in the most distinctive manner, considering the advisability of deduction in terms of intentions of its presentation as well as using sophisms and other linguistics structures in order to "win" the unaware and uncritical audience. As a result of the consideration of that issue and thanks to Aristotle's though, a distinction was drawn between the acceptable and the inappropriate methods of persuasion. ${ }^{43}$ However, it never brought the required effect in terms of eliminating the twisted techniques of sophistic argumentation.

Along with extending the area of the rhetoric interest beyond the sphere of law, jurisdiction and oratorical skills, also the application range of manipulative methods attained a lot of miscellaneous situational contexts. The most advanced and diversified forms of influence were developed in the area of public socio-political relations. The origin of the antic democracy and republic system turned the will of the majority into a key determining factor of state order, thus creating a strong demand for the most effective methods of influence on its decisions. The Greek speakers of the agora, referred to as demagogs (demagogos - the leader of people) and Roman tribunes slowly lost their original institutionally fixed position, concentrating mainly on winning the approval of the community in order to gain individual benefits and privileges. ${ }^{44}$ In that way, the alleged "leaders of the people" tuned into the leaders of the crowd - agitators of thoughtless masses of people deprived of their sovereignty.

The progress in developing effective and not necessarily ethical techniques of influence also took place on the external level - in the field of foreign relations. It was already determined by the specific nature of international relations functioning, since the dawn of time, in the realities of global anarchy and continuous conflict of interests between the corresponding forms of political, territorial or social organisations. Mutual contacts centred mainly on the disputed issues and the pragmatics of common interests viewed from the perspective of the highest possible potential benefits. An even more conducive context for improving the invasive methods of influence in foreign policy was created by the idea of expansionism, regarded by Machiavelli as one of the two basic objectives of the operation of a socio-political organisation (apart from striving to maintain freedom). ${ }^{45}$ Applying violence in order to fulfil the above mentioned conditions was often connected with high side costs that could considerably reduce or even exceed the expected profits. In other cases, the application of violence, in spite of the benefits offered, was difficult to introduce as a result of absence of appropriate justification. In such circumstances, it was necessary to use more subtle methods without compromising the primarily observed rule of maximum effectiveness.

In reply to the indicated challenges, the origins of full-dimensional diplomacy in the form of legations which required oratorical and eristic skills and even theatrical craft

43 Ibidem.

44 Giving a pejorative aspect to the originally neutral category of demagogy found its origins already in Plato's works and was related to the activity of the Sophists - this is where the contemporary idea of a demagog as a politician, a speaker announcing slogans meant to win an easy effect, applause of the masses who offers unjustified promises, creates illusions and puts forward irrational demands on behalf of the group; M. Karwat, Sztuka manipulacji politycznej, op. cit., pp. 94-95.

45 A. Riklin, Niccollo Machiavelli's Science on Governing, op. cit., pp. 83-84. 
emerged already in the ancient times. ${ }^{46}$ The dialectic and confrontational character of foreign relations, enhanced due to the importance and specific nature of high rank national and social affairs, constituted a motivating factor for improving all the accessible techniques of achieving political targets. As indicated by Francois de Callieres, a long-time French diplomat, an expert both in the theory and practice of foreign relations living in the XVII century, countries and their governments are forced to employ shrewd and cunning negotiators. Their significance consists, in turn, not only in collecting valuable information about the neighbourhood of the state but, first of all, as Clarrieres states, in the skills of "winning friends capable of opposing the intentions of the disturbers". Thus, an enlightened and careful negotiator should not only discover intrigues directed against the interests of the ruler but also defeat them. ${ }^{47}$ Taking into account the deceitful nature of international relations, the above mentioned author also emphasised the benefits resulting from the manipulative activities conducted by foreign legates. He claimed that at much lower costs, the usefulness of negotiators is equal to the usefulness of the standing army as they can "wake the forces of foreign countries and use them in favour of the prince [...] there is nothing more useful than a diversion made in due time by an ally". 48

The skills of diplomats (but not only theirs) in relation to the aspects mentioned above gained more and more sources of improvement, drawing inspiration from new theories and interaction concepts unknown so far. The development of psychology and progress in the investigations on human behaviours resulted in the creation of new specialised trends within the field of exerting manipulative influence. It was proved that in many situations the human mentality operates according to a generally determined mechanism. It was connected, first of all, with a specific nature of human behaviours within a social group. The exceptional character of those behaviours was noticed especially in the significant deficit of rationality and logic with respect to the level observed with reference to individual reactions. In that context, the pioneers of social psychology, Wilfred Trotter and Gustave Le Bon, claimed that group awareness cannot be identified with thinking in the literal sense of that notion. In the opinion of the aforementioned researchers, "impulses, habits and emotions" in group behaviours filled the place of reasoning understood in that manner. ${ }^{49}$ It was thanks to them that obedience towards the authority, a trusted leader and the community of group members became a common phenomenon in mass psychology.

A scientific approach to the process of group behaviours, represented by Trotter and Le Bon, was propagated and completed on the socio-political level by Walter Lippman and Graham Wallas. ${ }^{50}$ As a result of discovering successive regularities determining human reactions to influence, awareness and perception ceased to be the only objects of pressure in the process of imposing the desired patterns and attitudes. The interest of manipulators began to slip off beyond the sphere of shaping the mode in which a human

46 J. Sutor, Prawo dyplomatyczne i konsularne, Warszawa 2008, pp. 21-22.

47 F. de Callieres, Sztuka dyplomacji, Lublin 1997, pp. 34-35.

48 Ibidem, p. 35.

49 E. L. Bernays, Propaganda, op. cit., p. 50.

50 Ibidem, p. 47. 
being perceives the incentives from the external world, concentrating more and more on modifying the surrounding environment so that it could influence the objects of manipulation in the required manner. The influence of facts and events became particularly essential, pushing to the background their interpretation by the influence recipient. Manipulation became situational in nature, getting more and more distant from its linguistic roots. It was yet more difficult to capture by reducing its exposure and gaining new contents - the manipulator could gradually lose the necessary persuasive qualities and remain at a distance, allowing his own constructs of reality to "speak for him".

How effective but also destructive such interaction can be was proved by the investigations, quite significant not only from the point of view of psychology, conducted by an American investigator Stanley Milgram. His original idea was to carry out research aiming at a thorough analysis of the rules concerning social conformism. In order to reach that goal, he developed an experiment which included imitating the conditions and incentives that prompt an individual to follow the example of others who perform commands of the experiment holder and electrocute an innocent person. Prior to that, however, it was decided that control tests should be conducted and as part of those tests the objects were to be exposed to the pressure exerted exclusively by the experiment holder. ${ }^{51}$ Fascinated with what happens to people who, under commands articulated by an individual regarded as an authority, push the subsequent buttons of the electricity generator, Milgram focused on investigating the issue of obedience. ${ }^{52}$

The results of the above mentioned activities did not meet the expectations both of the scientific circles as well as of Milgram himself and of his associates. Simulations performed by the group of professors and students from the University of Yale indicated that the shock of the maximum voltage $(450 \mathrm{~V})$ was likely to be applied by 1-2 percent of the experiment subjects whereas the real index of complete obedience was approximately 60 percent. The percentage of people who continued the experiment in spite of the objections raised by the person who underwent allegedly painful shocks was even higher. ${ }^{53}$

Milgram's experiment was repeated many times, also in various configurations, and every time the outcomes confirmed the original conclusion. The basic result obtained was the ultimate inclination of an average individual to fulfil even the most controversial command of an authority. In spite of the fact that Milgram's conclusions were quite significant thanks to their empirical justification, they did not put forward revolutionary theses. Similar positions were presented already in the twenties of the $20^{\text {th }}$ century and

51 D. Doliński, Techniki wpływu społecznego, Warszawa 2005, pp. 13-14.

52 The discussed experiment was presented to the applicants as a test of pressure influence on the ability of remembering. Its participants played the role of a teacher applying electric shocks towards a simulated student in a situation of giving a wrong answer. The subjects were instructed to apply higher and higher "doses" of the electric current as long as the following mistakes occur. The accessible range of voltage considerably exceeded its safety levels, especially when the student claimed to have heart problems. In reality nobody experienced the electric shock - the recipient of the alleged shocks was a hired actor. R. Cialdini, Wywieranie wptywu na ludzi. Teoria i praktyka, Gdańsk 2002, pp. $186-187$.

${ }_{53}$ Ibidem, p. 188. 
were indicated by the representatives of social psychology Le Bon and Trotter as well as by Edward Bernays - theorist of propaganda, mentioned earlier.

The latter emphasised that the interaction between the authority and the object takes place even when an individual is forced to make his own independent decisions without being exposed to pressure exerted by anyone. The influence of the recognised authority is then fulfilled by means of clichés - images, slogans and symbols combining, in a simplified manner, impressions and experiences in the awareness at the cost of losing the real character of the designate considered. As demonstrated by E. Bernays, manipulating with symbols - creating and inserting new denotations under the old symbols is very effective as an individual is using them continuously, making every decision on their basis ${ }^{54}$.

All of the above mentioned theses discussing the authoritative aspect of manipulation acquired a special significance when confronted with the specific form of authority of the political power indicating the destructive potential and the range of enforcing public obedience. As numerous historical examples indicate, this type of influence easily gains international consequences and determines the character of foreign relations within the extensive perspective of time and subject. Sufficient amount of evidence was provided by the history of the $20^{\text {th }}$ century showing extreme cases of creating the international reality by means of the instruments of social engineering. The range of hazards related to that was revealed especially by the totalitarian systems of Nazi Germany, the Soviet Union and People's Republic of China or Democratic Kampuchea.

The social manipulation identified in this case with the degenerative concepts of propaganda and obedience to the authority of the state, could transform from a local phenomenon into an international or even global one. In spite of the fact that internationalization was the consequence of applying influence as a secondary form of the considered phenomenon (which does not exclude the globalization of manipulation itself), the fact of modifying the contents of international relations imposed the necessity of including the aspect of internal social influence into the discussed area. The tools of creating human awareness thus gained an unquestionable capability of stepping beyond the geopolitical and cultural boundaries of social organisations. The common denominator of their expansion was the relativization of meanings, conditions and interaction whereas the driving force took forms of improving influence distribution and new technical abilities of their application.

$* * *$

In 1958 Aldous Huxley, author of a visionary novel "Brave New World", revised his own vision of Future, formulated 27 years earlier in the aforementioned book. In published then study "Brave New World Revisited", he paraphrased Winston Churchill, pointing that, "never have so many been manipulated so much by so few". ${ }^{55}$ Those words sheds a light on the present circumstances showing a increasing relation between the sphere of individual influence and mass obedience. A. Huxley described in this

54 E. L. Bernays, Propaganda, op. cit., pp. 50-51.

55 A. Huxley, Brave New World Revisited, New York 2000, p. 19. 
manner conditions shaping the modern civilization, resulting in a inevitable gravity to the totalitarian system in a global sense. ${ }^{56} \mathrm{He}$ pointed that technological progress and ever quickening population growth will lead to unavoidable centralization and concentration of power, because mass and ever modern production require ever rising capital expenditures to keep it up. That can be only assured by big producers, resulting in disappearance of smaller competitors. Ever growing range of economical power in hands of ever diminishing social group leads to crystallization of small elite of power, controlling state institutions and influencing the society by efficient distribution of capital, information and even emotions. Tendencies expressed in such manner appear, according to A. Huxley, in both capitalist democracies and totalitarian states - the thing that differ is in the way the influence is used: ruthless in totalitarian system; modest and inconspicuous in democracies. ${ }^{57}$

Combination of previous considerations with Huxley's vision gives the picture of quickening expansion of manipulation techniques and rising amount of possible ways of their application linked directly to the means of civilization development. Achievements of many sociologists and psychologists in the matter of recognition of this case served equally in exposition, but also in improvement of manipulative forms of social influence. Their searches for common awareness resulted in confirming the existence of empirical and theoretically proven specific mentality of the mob, that differs from individual consciousness due to its emotional motivation which cannot be explained on the basis of individual psychology. Discovering mechanisms and motives of a collective perception gave clue for development of new techniques of influence allowing to control the social masses without noticeable trace. Pointed model found its application among others improvements under term of propaganda, proving that in certain circumstances and in limited scale social control is possible. Embodiment of those assumptions, and at the same time a dismal projection of destructive properties of manipulation, were $20^{\text {th }}$ century totalitarian systems of social influence.

Intensification of social-political interactions in the last century and rapid development of information and communications technology created special conditions for establishing new methods of shaping human awareness. Changes caused by expansion of mass media allowed widening the range of effective influence without increase of any distortion and making massage available to recipients in its genuine form. The public sphere have underwent thorough change as well, to that point limited only to the elite group of direct participants of political life - the civil society has become a very important cross point in a social-political communication system.

The bottom line of whole described processes was a certain paradox. When societies and nations established their own political awareness and reached for position of the sovereign in political system, at the same time more or less consciously accepted a role

56 In context of presently seen globalization and domination of liberalism, to describe the pathological forms of evolution of modern world system, subject literature uses terms democrature, or total democracy, that points at the progressing dogmatization of democratic values and vanishing social connection with created on their basis social-political systems. See: P. Pawełczyk, Koniec socjotechniki czy nowa socjotechnika, in: Dwa oblicza socjotechniki, (ed.) P. Pawełczyk, Poznań 2006, p. 53.

57 A. Huxley, Brave New World Revisited, op. cit., pp. 18-19. 
of object of political exchange between elites of power. Moreover, position of institutionalized distributors of information started to be taken over by non-governmental subjects, thus undermining the monopoly of authorities in this matter. In context of diplomatic relations, an important factor in keeping up the interest in the means of manipulation was the rise in significance of supranational groups - corporations, financial institutions and different groups of pressure, even the terrorist ones.

The fracture and spread of ability to exert pressure on the global scale even outside of public sphere was noted also in fields commonly regarded as an exclusive domain of government activity. It applied mostly to diplomatic relations, which in a world of global economy begun noticeably gravitating towards regulating economical issues. Supranational corporations and financial organizations focused on gaining biggest possible latitude and guarantees of safe development for their worldwide operations, have successively formed direct contacts with foreign governments and local societies. Within so called business diplomacy those subjects have gained also large capabilities of exerting social-political influence, making their way outside the sphere of public and civil control. Suggestive imagery of ever tightening ties between politics and economy becomes a tendency to hire former diplomats and state officials by business subjects in order to use their political contacts. ${ }^{58}$

On-going events showed, that aspirations for empowerment and direct influence on the ground of diplomatic relations has spread even further outside the public sphere. The case of Wikileaks and US Army PFC Bradley Manning (responsible for leaking the secret information) have shown the potential to breach the integrity of diplomatic system possessed by individual, informal initiatives within the society. ${ }^{59}$ In a globalized world, spheres of social and public activity have overlapped each other, and their interaction has starter to blear the initial differences. The symbols of those changes have become the international terrorist groups and informal organizations considered under the notion of cybercrime, which based their model of influence on ability to create the social anxiety. ${ }^{60}$

Extension of the field of active participants in social influence within international sphere determined further increase of natural rivalization and intensification of the conflicts of interests, which ever before were an integral part of diplomatic relations. Confrontational nature of international relations was emphasized by Henry Kissinger in context of nationalization which he recognized as the domination of national interests over "elusive values" and rivalry over cooperation which, in his opinion, is probably never going to change. ${ }^{61}$ Regarding earlier described rising role of supranational and non-governmental subjects, quoted notion should be revised to consider wider spread of holders of said interests, where interest of the state and society could be over-

\footnotetext{
58 E. Molendowski, W. Polan, Dyplomacja gospodarcza: rola i znaczenie w polityce zagranicznej państwa, Warszawa 2007, p. 56.

59 E. Sterner, Wikileaks and Cyberspace Cultures in Conflict, George C. Marshall Institute, February 2011, pp. 4-6.

${ }^{60}$ Both in sense of intentional activities of such groups for executing their own plans, as well as instrumental usage of prepared image of those by third party groups, perceiving a doctrine of creating fear as a chance to fulfill their own particular goals.

${ }^{61}$ H. Kissinger, Dyplomacja, Warszawa 1996, p. 19.
} 
whelmed by given particular goals. Prognosis alone and rule of calculated functioning of international relations is still valid. It is hard to expect, even in long term perspective, rejection of the deceiving scheme of influence so high rated for its effectiveness by practitioners of diplomacy.

Recent hopes for putting manipulative techniques out of the pool of the means of mass and diplomatic influence were based on the fall of bipolar world system as well as fall of many totalitarian regimes that had made manipulation a natural part of their system of social engineering. Those regimes were authors of classical examples of misleading affection and international manipulation. Most spectacular form of expressions were used in so called propaganda diplomacy. A representative example of such action was a column in "Le Monde" sponsored by North Korean government in order to have possibility to make references to allegedly favorable opinions in foreign medias. ${ }^{62}$

The development of liberal democracies did not lead to atrophy of such "tricks". Contrary, manipulation by means of mass media and instrumental usage of transmission in democratic systems become more sophisticated and harder to detect. Rules and values of free, unrestricted choice often were out of tune with the outline of behavior fitted into tight frames of political correctness and relativization of meanings. Civil participation in the political process risen a dilemma of satisfying the needs and demands for information. However, since society's share in political decision system has taken a dimension of legitimization, not the creative one, reglamentation and skilful control of the data flow has become the key factor in shaping the social stance. ${ }^{63}$

The triumph of democracy announced at the end of $20^{\text {th }}$ century and directly connected with the development of globalization, gave aforementioned conditions a common character. Attributes of those changes, such as social-economical liberalization and unification of separate social-cultural systems, not only has supported "copying" described model, but also distinctly expanded influential abilities of individual subjects in terms of international relations. In opinion of leading representatives of scientific community, such as Francis Fukuyama, Zygmunt Bauman or Benjamin Barber, globalization processes become impossible to tame in light of impulsive and uncontrolled character of their appearance. ${ }^{64}$ With such assumption, all conditions favorable towards distribution of influence on a major scale and creation of informational overload will remain a factor easing the usage of efficient means of manipulation in considered dimension.

\footnotetext{
ABSTRACT

In terms of specialization in social influence, the sphere of international relations is one of the most specific fields of social activity. Competitive and anarchized structure of international interactions works in favor of standard's relativization and dispersion of responsibility, which provokes use of ambiguously evaluated means of pressure. Legitimacy gained from Machiavel-

62 J. Sutor, Leksykon dyplomatyczny, Warszawa 2005, p. 99.

63 P. Pawełczyk, Koniec socjotechniki czy nowa socjotechnika, op. cit., pp. 53-55.

${ }^{64}$ M. Łukasik, Socjotechniczny mechanizm globalizacji, in: Problemy współczesnej demokracji w ujęciu socjotechnicznym, op. cit., p. 36.
} 
lian paradigm of effectiveness puts term of manipulation on the higher level in hierarchy of strategic social influence. The scope of its potential use is as broad as the field of diffusion between different scientific approaches to the issue of international manipulation. This shows the background for synthetic conception of social control, which simultaneously involves interest of various academic disciplines such as psychology, sociology and political science. Despite difficulties in grasping an equivocal substance of manipulation, both historical and theoretical context of its occurrence lead to consideration about its structural role in transformation of international sphere. Beyond the field of political realism, the case of legitimacy for manipulative influence is also undertaken within the reach of theories of constructivism. Suitable references to this issue reflect concepts of social control originally related to categories of rhetoric, diplomacy and propaganda. Under the common denominator of civil development strictly bounded to improvement of influential content and its distribution, all of mentioned factors build a wide area for research on manipulation within international environment.

\section{MANIPULACJA SOCJOPOLITYCZNA - INCYDENTALNA PATOLOGIA CZY IMMANENTNY SKŁADNIK RZECZYWISTOŚCI MIĘDZYNARODOWEJ?}

\section{STRESZCZENIE}

Pod względem poziomu specjalizacji w wywieraniu wpływu społecznego, przestrzeń relacji międzynarodowych zajmuje miejsce szczególne wśród wszystkich obszarów ludzkiej aktywności. Rywalizacyjna i zanarchizowana struktura zachodzących w niej interakcji sprzyja relatywizacji standardów i rozmyciu odpowiedzialności, które prowokują do stosowania niejednoznacznych aksjologicznie form nacisku. Umocowanie we wciąż aktualnym makiawelicznym paradygmacie skuteczności stawia manipulację na wysokim miejscu w hierarchii metod społecznego oddziaływania. Zakres jej potencjalnego zastosowania jest równie szeroki, jak obszar przenikania się odmiennych dziedzin naukowych podejmujących rozpatrywaną tematykę z punktu widzenia stosunków międzynarodowych. Wyodrębniona w ten sposób syntetyczna koncepcja sterowania społecznego obejmuje w porównywalnym stopniu obszary z pogranicza psychologii, socjologii i politologii. Pomimo trudności w uchwyceniu niejednoznacznej istoty manipulacji, historyczny i teoretyczny kontekst jej występowania skłania do rozpatrywania tego fenomenu w kategorii systemowej metody kreacji rzeczywistości międzynarodowej. Poza nurtem realizmu, rozważania nad zasadnością sterowania społecznego w stosunkach międzynarodowych dopuszczają również orientacje konstruktywistyczne. Zawarte w nich odwołania stanowią odzwierciedlenie konceptów sterowania społecznego wiązanych z kategoriami retoryki, dyplomacji i propagandy. Zebrane pod wspólnym mianownikiem rozwoju cywilizacyjnego i postępującego wraz z nim usprawniania kanałów dystrybucji wpływu, tworzą szerokie pole dla badań manipulacyjnego oddziaływania w sferze międzynarodowej. 
